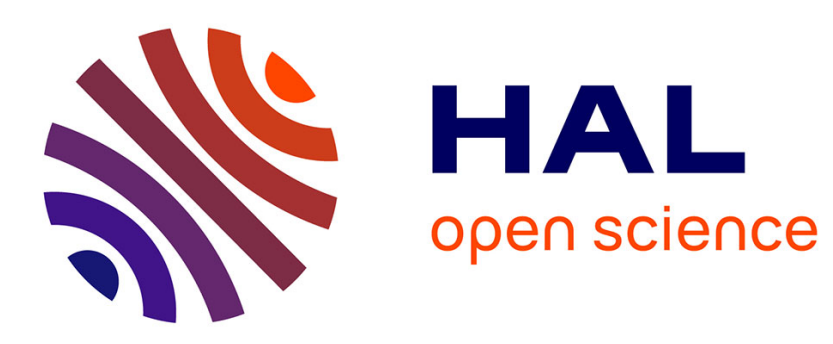

\title{
Issues of Social Memory and their Challenges in the Global Age
}

\author{
Elżbieta Halas
}

\section{To cite this version:}

Elżbieta Halas. Issues of Social Memory and their Challenges in the Global Age. Time \& Society, 2008, 17 (1), pp.103-118. 10.1177/0961463X07086305 . hal-00571038

\section{HAL Id: hal-00571038 \\ https://hal.science/hal-00571038}

Submitted on 1 Mar 2011

HAL is a multi-disciplinary open access archive for the deposit and dissemination of scientific research documents, whether they are published or not. The documents may come from teaching and research institutions in France or abroad, or from public or private research centers.
L'archive ouverte pluridisciplinaire HAL, est destinée au dépôt et à la diffusion de documents scientifiques de niveau recherche, publiés ou non, émanant des établissements d'enseignement et de recherche français ou étrangers, des laboratoires publics ou privés. 


\title{
Time \\ Society
}

\section{Issues of Social Memory and their Challenges in the Global Age}

\author{
Elżbieta Hałas
}

\begin{abstract}
The social experience of time is investigated in connection with the transformation of global power relations expressed symbolically. Collective memory in postmodernity is featured as a temporal distinctiveness of the global age. Consequently, problems of the politics of memory, followed by conflicts of memory come to the fore. Symptomatic for postmodernity in the context of globalization is the phenomenon of reshaping problems of memory into social problems. The global politics of memory and globalizing symbolic conflicts over memory are a new phenomenon. They are exemplified by the problems of memory in post-communist countries, with the focus on the case of Poland. KEY WORDS - collective memory • globalization $\bullet$ politics of memory $\bullet$ post-communism $\bullet$ symbolic conflicts
\end{abstract}

Two very broad notions applied to the characteristic changes at the turn of the century and at the beginning of the new millennium, globalization and postmodernity, arise from two different metaphors: a spatial metaphor that refers to the connections of social phenomena in a world scale and a temporal metaphor that signifies a new historical epoch. In fact many authors have attempted to identify some new spacio-temporal relations of social phenomena (Fougeyrollas, 1994; Mongardini, 1994). Attention has been focused in particular on the disappearance of temporal and spatial distances, new forms of simultaneity of events and experiences, or the phenomena of space-time compression (Harvey, 1990: 284-285). 
However, without questioning the importance of that dimension of change, the problem of social time in the processes of globalization must be somehow tackled differently through more relevant processes than the noticeable weakening of the importance of chronology and evanescence of undifferentiated temporality, especially in media communication, or even in the particular timelessness of multimedia's hypertext (Castells, 2000: 492). It is an oversimplification to claim that in postmodernity we witness a transition from the modernist regime of history and the idea of progress to the regime of space with the subsequent simultaneity of events, their fragmentation and varied temporality causing time to lose its meaning as an orderly sequence of events (Castells, 2000: 497).

It needs to be emphasized that the very notion of postmodernity is par excellence a temporal category, a representation crucial for the constructing and transforming of historical consciousness. Postmodernity, being an interpretive category of historical change taking place, is simultaneously its articulation and a causative idea for further cultural change, expressing the relation of the interested knowledge elites to expected and promoted change. It is not a category that emerged from quotidian experience, originating rather from that cultural level of sense production that has a potential ability to shape common experience itself. Thus, the hypothesis that culture has become a battleground (Wallerstein, 1990) refers also to the experience of time and its symbolization, i.e. to conflicts about the symbolic representation of ongoing changes.

\section{Collective Memory in Postmodernity}

The meaning of time, including the past, constitutes a deep level in the structure of culture, or, in other words, a fundamental principle of its construction (Le Goff, 1992: 11). For instance, in antiquity the past had been valued the most, as opposed to the decadent present. During the Middle Ages, the eschatological eternity was of predominant concern, while the present came to the fore during the Renaissance period. For modernity, the characteristic feature of time was the ideology of progress, valorizing the future. The widely discussed end of the 'grand narratives' may also be interpreted as a hypothesis that refers to the reevaluation of dominant temporal orientations of past eras in such a way that neither mythology nor eschatology nor history any longer ascribes possible prevailing order-setting meaning to the experience of time.

The phenomena characterized earlier accompany the so-called postmodernist turn. If it were to signify the new era it would, just like in the past epochs, mean a substantial change in the understanding of time and the attitude towards the past; i.e. different from the ones witnessed in modernity. Postmodernism seems actually to be the era of multiple temporalities - many ways of experiencing 
time - simultaneously interacting, without any order-setting structure, competing for the recognition of their attractiveness. Francis Fukuyama's claim of the end of history which, if understood literally, seems absurd and also controversial for those who do not agree that liberal capitalism is the culmination of historical development, can be interpreted in a less trivial way as a hypothesis that refers to the crisis and weakening of those cultural codes that maintained the historical embeddedness of Western societies (Castells, 2000: 449), including, for instance, the symbolic codes of historical Christian religion.

It is, however, possible to indicate a more crucial characteristic of postmodernity as far as the social experience of time goes: the problem of social memory and especially collective memory, which seems most distinctive for the changes of postmodernity. Collective memory is not entirely in opposition to the rationalizing historical knowledge about the past. Nevertheless - contrary to modernity - in postmodernity it is again the collective memory that comes to the fore, or rather it is the multiplicity of collective memories as the result of the disintegration of the uniform historical memory and tradition. One may understand postmodernity from the perspective of the remarkable new phenomena - the growing significance of the collective memory, the globalization of collective memory ${ }^{1}$ and conflicts of collective memories.

Social memory has a direct referent only in its distributive dimension, i.e. when related to the memories of many individuals, the members of a society. In its collective aspect, memory is only a metaphor because there is no actual memory of a society as a whole. What is meant by the term are the processes of communication and symbolic representations of the past experiences of a group.

Characteristic for the modern change has been to set history against memory through communities that rationally investigate and reflect on their history versus the temporality of traditional communities. That opposition is of an idealtypological and schematizing character while collective memory is more elementary. Collective memory has not vanished but in modernity it surrendered to the significance of history and to the hegemony of historical memory. The characteristic feature of modernity was the transformation of ethno-symbolic collective memories into historical memories. The agency making that possible was the national state. At present, attention is paid to the opposite tendency: to localities, regionalizations, pluralization of narrations and the multiplication of collective memories manifesting themselves in various ways. However, this process of the revitalization of collective memories has two tendencies; it becomes not only local, but it is simultaneously the subject of globalization.

Although modern historiography attempted to present the history of the world, or world history, the phenomenon of global collective memory is a relatively new one, linked to the modern world wars and their consequences that transformed the memory of Europe and the world. In the perspective of the 20th century, the time between the two world wars is so short that they actually mark 
one period of world wars that has unintended consequences in the form of globalizing collective memory. That memory, with common frameworks of traumatic social experiences, is actually differentiated and pluralistic. Different narrations compete symbolically in the public sphere for legitimate interpretation going as far as the transformation of the basic frameworks of meanings: the definition of allies, enemies, victors and the defeated, liberation and enslavement. The celebration of the 60th anniversary of the end of the Second World War revealed these tendencies and, particularly, the public discourse in postcommunist countries.

In the 20th century, after the Second World War, historical memory had a clear structure analogical to the divided structure of world relations, i.e. the First, Second and Third Worlds (Le Goff, 1992: 131). As a consequence of the collapse of the Second World of communism, the Third World - dependent on the relations between the first two - also underwent a process of transformation bearing consequences for both historical memory and collective memory. The latter became free to operate with subversive effects on the earlier politics of historical memory.

The Second World War and the Cold War caused great divisions in collective memories. Wars have always been significant temporal makers, but the Second World War gave that phenomenon a global character. Historians do their research and the resulting verified knowledge about the past events constantly keeps increasing - although the historical knowledge is not the decisive factor influencing the future of societies - nonetheless, social memory and the politics of collective memory may or may not rely on that knowledge. New tendencies in temporal orientations characteristic of the global age prove that their significance becomes more and more important in power relations between various social groups.

The earlier, modernist, sharp distinction between popular, collective memory and legitimate historical memory is fading. The growing production of collective memories, with the contribution of the media, affects history that remains under the influence of many collective memories. The so-called 'new history' aims at doing historical research on the basis of collective memory (Le Goff, 1992: 95). In historical studies practiced in such a manner linear temporality is rejected in favor of numerous, often varied experiences of the past and different oral histories.

Under the pressure of collective memory and its growing relevance, a longdebated issue becomes significant: is history a science about the past, or does only contemporary history exist, i.e. relative historical knowledge serving the construction of the present and the future? Marc Bloch rejected the commonly accepted definition of history as a science concerned with the past, suggesting a definition of history as a science studying people in time (Le Goff, 1992: 106). According to such a proposal, history was to help in the understanding of the 
present with assistance from the past, and contribute to understanding the past with the help of the present. The idea of history actually being dominated by the present is related also to the idealistic theory of Benedetto Croce who claimed that all history is present-day history. From such a point of view the past is being continuously constructed and reinterpreted. The interaction between the present and the past is seen as a social function of the past (Le Goff, 1992: 109). Realism, on the other hand, assumes that it is necessary to keep a distance in relation to the past in order to avoid various forms of anachronism. Thus, history remains a science concerned with the real past, which is the object of investigation by continuous reconstitution and questioning in the light of new facts characteristic of scientific knowledge as such aiming at objectivity (Appleby at al., 1994: 25 ff.).

Collective memory is defined most often after Maurice Halbwachs as a group's memory of its own past, which allows it to define its identity in relation to other social groups (Fine, 2005). Collective memory consists of the reconstructed images of the origin and the development of a group that permit it to identify itself in time. It is produced by transmitting knowledge about group experience from generation to generation. Collective memory cannot be reduced to autobiographical memories or equalized with historical memory. The vehicles of that collective memory are both public discourses and various forms of performative actions, most often in the form of commemorative rituals (Connerton, 1999).

Collective memory is also defined as what remains from the past in a group's experience of reality, or, to put it more accurately, what the group makes of the past (Le Goff, 1992: 95). Memory, along with the closely related commemoration, belongs to the leading subjects in research of its social construction, including politics of memory. Most importantly, it constitutes not only a specialized branch of investigations, but it is also crucial for the identity formation of various social groups, associations, nations and international organizations. Halbwachs stressed the opposition between historical knowledge and collective memory (Zerubavel, 1995: 4). Currenty, the departure from this modernist opposition is visible and indicates the social conditions and social functions of historical knowledge, the relativity or limitation of interpretive perspectives as argued by constructionists. According to Barry Schwartz, the past is not constructed in the literal sense but only 'selectively exploited' (Zerubavel, 1995: 5). History and collective memory remain interdependent and the practice of commemoration remains a key element for their relations. Public commemorations are also crucial for understanding the continuity or changes of collective memory (Hałas, 2002).

Commemorative performances more or less openly transmit and reproduce commemorative narratives containing the justification for ritualized remembering, as well as including cautionary tales. The historical message is used for such 
purposes selectively, since commemorations are always fragmentary, and the choice of what would be commemorated and what meanings of the past would dominate is part of the politics of memory. In those cultural constructions, one can see master commemorative narratives containing some legitimate general notions referring to the past to be shared.

In the activities of elites aiming at spreading modern national consciousness, history has been a key instrument. The development of national consciousness has assumed the development of the uniform historical consciousness, enabling all members of a national community to participate in what Edward Shils calls, a central system of group values (Shils, 1982: 106). One of the consequences of these processes was the emergence of modern nationalisms: the manifestation of collective identity exclusiveness, one of the major social and political problems of modernity, and its ambiguous heritage. The dispute concerning the understanding of the phenomenon of the nation between primordialists, who claim a natural priority of a national community, and constructionists, who see the nation as an artificial product, is not only theoretical but also reveals the different valuations of national memory and conflicting political options of various temporal orientations as a social problem.

The conflict of perspectives carrying different evaluations of the past is one of the many conflicts taking place in the cultural dimension and is perhaps particularly significant for the future. The concept of civic nations, emphasizing the state and constitutionally guaranteed civil rights, and the cultural concept of the nation stressing a long-term participation and creation of common cultural values, assumes respectively the inclusive or exclusive understanding of collective memory - the former allowing the multiplicity of memories, the latter very narrowly defining the legitimate community of memory.

The conflict between inclusive and exclusive approaches to collective memory appears in Europe in complicated configurations. Not only have different nations owned particular narrations about the collective past foundational for their states or aspirations to have them, but also Eastern and Central Europe have witnessed the installations of states based entirely on constructivist communist programmes. These programmes were anti-national in their politics of memory, excluding national traditions, manipulating the traditions, and transforming the memory of the collective past. Compared to modernist revolutions, the French Revolution and the Bolshevik Revolution, the transformation in Europe after 1989 - with the exception of Romania and the Balkans - was not that deeply traumatic an experience. And the powerful, 'revolutionary' politics of memory has not been exercised. A more general pattern of change has been the liberal democracy and that is why on the market of public discourses the communist memory has not been excluded. It has become a serious political problem as a source of continuous contestation by those claiming it an obstacle for an axiologically based democratic civic community, not merely a formal and legal one, 
insisting on reckoning with the communist past. ${ }^{2}$ The post-comunist transformation and the unification of Germany disturbed the official, petrified politics of memory of the Second World War and its consequences, and has given origin to the processes of the regaining of memories that do not cease to be divided. As a result, also in this context, local duties of the memory of trauma are often interpreted as endangering reputations (Fine, 2001: 17) of national communities or creating dangers to their interest in the future as exemplified by the programme of building the Centre Against Expulsions in Berlin.

An unexpected consequence of a modern process consisting in the development of a civil sense of the masses (Shils, 1982: 107) is the development of populism. Populism based on the conviction of the superior values of the common people and their abilities (Shils, 1982: 199) manifests itself in various ways. One can even attempt to prove that its development was inadvertantly aided by social sciences - and not ideological in principle - especially by the broadly understood sociology of everyday life, research based on the biographical method, and oral history. The democratization of memory in public discourse followed and various social groups reconstructed their roots in the past, thus constructing the equivalence of genealogies. As far as collective memory is concerned, the term itself may have a populist connotation and indicates such articulations of past meanings that differ from rationalizing history and elitist tradition which are subject to authoritative explanation that requires authorized guards.

This common revitalization of interest in collective memories is also an unexpected effect of the media revolution and all the techniques that make it possible to record and distribute various representations of past experiences. That is why one may speak of an immediate history fabricated by the media that produces increasingly differentiated collective memories. Additional new phenomena are various plebiscites of memory in the form of popularity polls for persons or events from the past. Memory in such cases may become playful or ludic: in this manner the past may be deprived of solemnity and authority. The lack of responsibility for memory occurs and there are frequent infringements on collective memory - a kind of symbolic violence. The rules of communicating past experiences are unclear and consequently the irresponsible utilization of memory occurs, although in response various institutions have been established with the goal of protecting memory. ${ }^{3}$

\section{Politics of Collective Memory}

Insofar as the politics of historical memory had been within the domain of the state, the beginning of the 21 st century witnessed a perceptible growth of the significance of the politics of collective memory on a global scale, including 
attempts at a global politics of memory. In this respect its important functions such as legitimization of the social order, formation of collective identities, and idealization of values should be taken into account. The attempts at its uniformization could not be successful. Instead of a similarity and uniformity of global memory, differences multiply.

Since the 19th century, modernity has been characterized by strong constructionist politics of memory harnessing history for its purposes. In postmodernity, after the desintegration of large political 'blocks' there is a clear revitalization of collective memories, the appearance of various anti-memories (falsification of memory), countermemories (different and conflicting interpretations of the past), unofficial or apocryphal memories in relation to existing canons. This does not mean that a modern politics of memory is disappearing, which may be exemplified by the attempt at reconstructing the Russian empire with the use of symbolic instruments that belong to the politics of historical and collective memory. The modern symbolic politics of the European Union, whose historical memory is weak in comparison to the memories of European nations and nationstates, has also been built with the use of modern strategies of symbolization of collective identity imitating state symbolism (an emblem, anthem, or the proposed Constitution of the European Union).

As far as the memory of the past is concerned, Europe undergoing the process of unification is a good example of the deep divisions being uncovered by the old and new European Union member states. The cultural aspect of integration is most unclear due to those differences of memory and tradition that cannot be standardized and conformed to many parameters that are in force in member countries, in contrast to procedures, regulations and products. Attempts at creating a global framework for collective memory are visible in the activities of the United Nations that try to arrive at valid interpretations of historical experiences on the global scale. An important subject of these attempts is also the global media. Many nations and communities, with the assistance of these institutions, undertake communicative actions, attaining mixed results as far as the efficiency of politics of memory is concerned. They compete for memory in such a way that one can speak even about symbolic wars of memory. What is symptomatic here, and at the same time problematic, is the multiformity-differentiation of the politics of memory and their interpretations both as far as the articulated goals and possible consequences are concerned.

New and symptomatic for postmodernity in the context of globalization is the phenomenon of the reshaping of problems of memory into social problems that are - to use the neologism introduced by Roland Robertson - 'glocal', i.e. local with global consequences and vice versa. The global politics of memory and globalizing symbolic conflicts over memory are a new phenomenon. They became especially evident in 2004-2005 during the commemoration of the 60th anniversary of military campaigns that led to the end of the Second World War. 
Those events determined the fate of nations for over half a century. The politics of historical memory after the fall of communist regimes and the reunification of Germany was subject to deregulation and led to the emergence of a pluralism of collective memories. The clearest manifestation of related problems is the victimization of Germany that resulted unexpectedly from the policy of nonmemory, or the amnesia of the German nation's suffering during the final stage of the Second World War and immediately after. From the very beginning the problem of expelled Germans has been articulated by their associations and has played an important role in Germany's internal politics. However, as a result of Allied Forces operations, the destruction of German cities and numerous civilian casualties are only now becoming a contested subject of discourses that require a subtle politics of memory between pacifism and nationalist radicalism. Along with the strengthening of memory as a social problem on a global scale (glocalization of collective memory), its manifestations tend to inceasingly resemble the activity of strategic communicative actions. Among such strategies are nostalgia or amnesia in relation to the collective past, observed, for instance, in the post-communist states and the reunified Germany. ${ }^{4}$

It is noted that the construction of collective memory implies a competition between the linear and cyclical perception of history, i.e. the continuity of experience in time and returns, or repetitions. Collective memory distinguishes social groups, and changes in commemorations of their origins are the means of group identity transformation, as was the case in communist countries after the Second World War. In such cases as mentioned earlier, one can observe the phenomenon of the so-called great divides of collective memory (Zerubavel, 1995: 7). They occurred both after the First and the Second World War. Particularly problematic are those constructions of the great divides in collective memory that, while assigning a new meaning to a group experience, offering principles of periodization and imposing a new order on the experience of the past, conflict with the existing group memory and remain in conflict with the collective memory of other groups.

Among the techniques used in the construction of collective memory, one should distinguish the so-called commemorative density. The term was introduced by Claude Lévi-Strauss, who pointed out the variable intensiveness of commemoration of various past periods. When commemoration fades away one can, after Sigmund Freud, speak of collective amnesia (Zerubavel, 1995: 8). Memory and oblivion (Ricoeur, 2000: 574-589) are subject to fluctuation and change. They are influenced by many factors that Lévi-Strauss defined in general as the pressure of history (Lévi-Strauss, 1969: 388), i.e. the great number of events that are important at a given historical period. Ernst Renan claimed that oblivion is necessary when an event divides a community, particularly a national community (Stråth, 2000: 25), and analogically, a larger community. There can be a discrepancy between the memory of the past of a 
particular group and the historiography of its experiences. The latter in turn can influence the memory of a group, as was the case under the communist regime. The collective memory of the violence during the regime's installation is being regained to the extent that detailed, previously hidden data are concerned.

When some events of the shared experience are remembered by one social group and forgotten by another, we witness a more problematic situation in mutual relations of groups than if different memories of the same events compete. This is often the case in mutual relations of the European countries after the fall of communism.

Commemorative time should be distinguished from historical time (Zerubavel, 1995: 9). At a time when, as in the case of the great transformations in Europe and the world after 1989, one is looking for frameworks of meaning, then in the construction of collective memory an important function is played by the choice of such events which can become symbols of change, although the change itself took longer. This leads to a certain schematization and ritualization of collective memory. In that context Edward Shils speaks of the so-called great moments which are believed to have directed the development of events and which give the past a certain aura of sacredness (Zerubavel, 1995: 242). There emerges the problem of the possible deformation of interpretation regarding the historical process and of overshadowing important meanings by an arbitrary choice of one event at the expense of others. A good example of that problem in interpreting the transformation in Europe after communism is the symbolic function of the Fall of the Berlin Wall in 1989, which in the global politics of collective memory became a dominant symbol at the expense of the symbolism of 'Solidarity' that in 1980 challenged a communist regime. The choice of that, and not some other event, as a turning point is related to the ideological principles of constructing the dominant commemorative narratives that dramatize the transition from one period to another. When they become separate from their historical context and become a part of the symbolic text as a paradigm for understanding change, then the process of shaping political myths takes place (Tudor, 1972: 137-140). A political myth provides a perspective that determines the meanings of the present as well as collective actions in the future. The turning points, or great moments - as symbolic designates of change - are particularly subject to mythologization (Zerubavel, 1995: 9).

An important symbolic function of representing the historical transition makes the turning points more ambiguous when compared to those events that, in the main commemorative narratives are placed in clearly separated periods of the past, analogically to the liminal period in rites of transition, i.e. between separation from the past experience and renewed incorporation into community (Turner, 1974: 81). One of the characteristic features of political transformation, or the post-communist transition, is that the turning points between various historical periods in group experience can be subject to different interpretations. 
If the conflicts and discrepancies in the interpretation of political myths are too large, they can lead to the destruction of a myth and to the confrontation between opposing interpretations of the past. That phenomenon can be observed in Poland, for example, in relation to the myth of 'Solidarity' and attempts to mythologize the Round Table talks, i.e. the agreements between the representatives of the opposition and the top functionaries of the regime in 1989 leading to the breakdown of the communist system.

Alternative commemorative narratives are directed against the hegemony of the dominant commemorative narrative and create countermemory. A symbolic conflict like that always takes place in a political context and usually countermemory is created by marginalized groups that remain in conflict with the dominant ones. Sometimes the situation is reversed. Groups engaged in a political conflict promote competing visions of the future (Zerubavel, 1995: 10,11). The concept of countermemory was introduced by Michel Foucault who pointed to the oppositional, subversive constructions of meanings of historical events, but generally speaking they are a part of comprehensive frameworks of meaning related to the past (Zerubavel, 1995: 243). Minority or dominated groups are often subject to persecution when practicing their separate collective memory.

Countermemory is a cultural factor driving the changes, and their direction can be observed when one investigates the reshaping of countermemory into the dominant commemorative narratives. A very telling example is the commemoration of the Katyn massacre by the Soviet secret police (the NKVD) in 1940 of over 22,000 Polish officers taken prisoner in September, 1939 when the Red Army annexed the Eastern territories while Poland fought the German invasion. In Poland, after 1989, the restoration of the memory of the Katyn genocide legitimized the post-communist changes in the early 1990s. In international relations between Poland and Russia, the Katyn issue continues to be an unsettling one and the symbolic conflict over declaring the crime as genocide by Russia remains unresolved.

The rhetoric of continuity and change remains an important aspect of constructing collective memory and differentiates conservative and reformist or revolutionary movements respectively. However, it is possible to observe a much more complex politics of memory towards the past, which can be uncovered within research of commemorations (Zerubavel, 1995: 214 ff.). Conflicts over collective memory expose historical and political divisions, both within states and in relations between them. Indeed, the term 'collective memory' is not quite adequate because we are dealing with multiple memories (Zerubavel, 1995: 235), and their growing multiplication is undoubtedly a serious social problem on a global scale when these memories contradict themselves.

The post-communist transformation released the reconstruction processes of representations of the past in Europe. The characterization of those processes, limited to what was called the reclaiming of memory (Le Goff, 1990: 7), is 
somewhat simplified because it does not take into account their complexity and the problematic character of a new game of memory and non-memory, amnesia and nostalgia, memory and countermemory.

One should notice that the reconstruction of collective memory after communism is limited in its time-frame. Although sometimes (e.g. in symbolic conflicts over collective memory between Poland and Russia after 1989, where the Polish-Russian war conflict of the 17 th century is recalled) ${ }^{5}$ the memory does not basically reach further back than the period of the First World War and its consequences, above all the Bolshevik Revolution of 1917. The PolishBolshevik war of 1920 belongs to the category of regained memory in Poland, repressed under the communist rule. The regained memory and its symbols can have a liberating power but it also poses a serious problem in relations between Poland and Russia. As far as Polish-Russian relations go, the difference between collective memories of the Second World War are critical and evoke deep divisions. For the Poles, the war began with the German invasion on September 1, 1939, but for the Russians it started in June 1941 with the German operation Barbarossa, as a great war for the homeland. Therefore, what is meaningful in Poland with the regained possibility of commemoration of the Soviet aggression on the Eastern territories in September 1939, on the basis of the Molotov-Ribbentrop Pact, is subject to amnesia in the collective memory of Russians. This happens not only as a consequence of the Soviet politics of symbolization but also as a result of differences between respective collective memory, Polish and Russian, structuralized in different ways by the historical traumatic experience.

In the context of post-communist changes and the liberation of nations from the Soviet hegemony the relation of different and divided collective memories in countries aspiring to democracy is even more complicated. Another telling example of symbolic conflict over collective memory can be found in the relations between independent Ukraine and Poland. One symbolic sign of these relations has been the ability to reach a compromise over the commemoration of the Polish defenders of Lviv ${ }^{6}$, which before the partitions of Poland in the 18th century by Prussia, Russia and the Habsburg Monarchy was a Polish city. In 1918, when Poland regained independence, Lviv became an object of territorial aspirations of Ukrainian nationalists that resulted in an armed conflict. Lviv remained within the borders of the Second Republic of Poland and its defense was an object of careful commemoration politics of the Polish state before the Second World War when the Cemetery of the Lviv Eaglets was built. Lviv was taken over by the Soviets during the above-mentioned invasion in September 1939 and, as a consequence of the Yalta Conference, became a part of the Soviet Union and now belongs to the independent Ukraine. The commemoration of Polish and other defenders of the city through the opening of a renovated cemetery on June 24, 2005 was possible - although not without difficulty - only after 
the Ukrainian democratic 'Orange Revolution' of 2005. Hitherto, PolishUkrainian relations have been marked by traumatic events experienced by both nations. Coping with this heritage of Polish and Ukrainian collective memories in a way that makes the reconciliation possible is a painful political issue, potentially subject to exploitation by identity strategies that could lead to new antagonisms.

Collective memory as a social problem manifests itself with remarkable force when it refers to a memory of trauma (Giesen, 2000), i.e. the experience of war, deportation, genocide. Only after 1989, in Poland, was the full recovery of the memory of the Warsaw Uprising against Germans in 1944 possible (Davies, 2004) or, to be precise, the recovery of the possibility of its proper commemoration banned by the communist regime. The memory of the Warsaw Uprising that was started to prevent the Soviet forces from liberating the city from Germany has always been alive, but eliminated from public discourse by the communists. For sixty years the Warsaw Uprising remained within the area of amnesia even in the free world countries because of its subversive character in the context of the post-Yalta political order. The interactive museum of the Uprising, opened in Warsaw in 2004, complies with the duty of memory and records the GermanPolish conflagration that remains a challenge for the politics of memory and reconciliation in processes of European integration.

The earlier examples testify to the enormously complex problems of symbolic politics of memory that follows from questioning the political status quo. Despite processes of European integration and globalization, it is not easy to overcome old nationalisms. Moreover, new projects to construct national identities do not cease to emerge. They are based on new politics of identity and memory and their symbolic representations, e.g. creating political representations of ethnic communities aspiring to get certified as nations (Tilly, 2001).

The politics of memory, particularly of the traumatic kind, where the possibility of reconciliation and harmonization between conflicting groups is concerned, can be practiced basically in two ways. The character of the first kind of politics is expressed by the etymological proximity of amnesia and amnesty (Ricoeur, 2000: 586) and such politics marked for example by the period of transformation in Poland as far as the communist past is concerned (the socalled policy of 'the thick line'). It competes with the politics of meticulous investigation of the past and reckoning with the past. The second one can have two variants: a legalistic one aiming at investigation and justice, and a utopianethical one stressing the principle of forgiveness, i.e. moral transformation that transcends the realm of politics. Each one of these politics carries antinomies; the equilibrium between memory and oblivion, therefore, remains a challenge as a manifestation of responsible internal and international politics.

Contemporary, constructionist approaches are conducive to the blurring of the difference between objectivizing history and the subjectivity of memory 
(Stråth, 2000: 19). The problem of memory is simultaneously a problem of identity, individual or collective. Questioning the concept of objective reality and truth when it is transferred from the level of epistemological analysis to the interpretation of memories of the past becomes a political phenomenon. If the interpretation of historical facts becomes relative and when various collective memories compete for defining the past, the legitimization of interpretations they provide could ultimately be decided, in a dangerous way, in the domain of real politics.

\section{Notes}

1. On the significance of the Holocaust in this process see for example Levy and Sznaider (2006).

2. Communism, as opposed to Nazism, has not achieved the same status of atrocity for many reasons that will not be analyzed here (Besançon, 2000).

3. The wording 'Polish concentration camps' that appears in the global communications media is an example of the gravity of the problem. The expression infringes upon historical truth about the genocide committed by Nazi Germany on the territories of the occupied Poland and affects the reputation of the Polish nation. Preventive actions were taken by the Polish state institutions and non-governmental organizations (see 'Statement by His Excellency Mr Adam Daniel Rotfeld, Minister for Foreign Affairs of the Republic of Poland', Fifty-ninth session of the General Assembly of the United Nations. Commemoration of the sixtieth anniversary of the end of the Second World War. Available at: http://www.polandun.org/templates/statementRotfeld09may.html)

4. We concentrate our attention on Europe, or the so-called 'New Europe'. Other important and painful issues that can be described as 'postcolonial memory' in other continents are not discussed here.

5. In Russia, 4 November is the National Unity Day celebrated since 2005. It commemorates the ejection of the Polish-Lithuanian occupying forces from Moscow in 1612.

6. Among the defenders there were also volunteers from the USA and France.

\section{References}

Appleby, J., Hunt, L. and Jacob, M. (2000), Powiedzieć prawdęo historii, Poznań: Zysk i S-ka Wydawnictwo. [Original edition: Telling the Truth About History. New York: Norton, 1994].

Besançon, A. (2000) Przekleñstwo wieku: O komunizmie, narodowym socjalizmie $i$ jedynoæci Zagady. Warszawa: Czytelnik. [English edition: A Century of Horrors: Communism, Nazism, and the Uniqueness of the Shoah. Wilmington, DE: ISI Books, 2007]

Castells, M. (2000) The Rise of the Network Society, Vol. 1. Oxford: Blackwell.

Connerton, P. (1999) How Societies Remember. Cambridge: Cambridge University Press. 
Davies, N. (2004) Rising '44: The Battle for Warsaw. New York: Viking.

Fine, G. A. (2001) Difficult Reputations: Collective Memories of the Evil, Inept, and Controversial. Chicago, IL: University of Chicago Press.

Fine, G. A. (2005) Collective Memory, in G. Ritzer (ed.) Encyclopedia of Social Theory, pp. 116-17. Thousand Oaks, CA: Sage.

Fougeyrollas, P. (1994) 'L'Attraction du Futur', The Annals of The International Institute of Sociology 4: 223-30.

Giesen, B. (2000) 'National Identity as Trauma: The German Case', in B. Stråth (ed.) Myth and Memory in the Construction of Community. Historical Patterns in Europe and Beyond, pp. 227-47. Bruxelles: Peter Lang.

Hałas, E. (2002) 'Public Symbols and Polish Identity: Change and Ambiguity of Meaning in State Holidays Calendar of the Third Republic of Poland', in E. Hałas (ed.) Symbols, Power and Politics, pp. 81-100. Frankfurt am Main: Peter Lang.

Harvey, D. (1990) The Condition of Postmodernity. Oxford: Blackwell.

Le Goff, J. (1990) 'Preface', in A. Brossat, S. Combe, J.-Y. Potel, J.-Ch. Szurek (eds) À l'Est la mémoire retrouvée, pp. 7-10. Paris: Éditions la Découverte.

Le Goff, J. (1992) History and Memory. New York: Columbia University Press.

Lévi-Strauss, C. (1969) Myśl nieoswojona, trans. Andrzej Zajączkowski. Warszawa: Państwowe Wydawnictwo Naukowe. [English edition: The Savage Mind, Chicago, IL: University of Chicago Press, 1966]

Levy D. and Sznaider, N. (2006) 'The Politics of Commemoration: The Holocaust, Memory and Trauma', in G. Delanty (ed.) Handbook of Contemporary European Social Theory, pp. 289-97. New York: Routledge.

Mongardini, C. (1994) 'The Culture of the Present. The Changing Attitudes to Time in Late Modernity', The Annals of The International Institute of Sociology 4: 231-7.

Ricoeur, P. (2000) La mémoire, l'histoire, l'oubli. Paris: Éditions du Seuil.

Shils, E. (1982) The Constitution of Society. Chicago, IL: The University of Chicago Press.

Stråth, B. (2000) Introduction: Myth, Memory and History in the Construction of Community, in B. Stråth (ed.) Myth and Memory in the Construction of Community: Historical Patterns in Europe and Beyond, pp. 19-46. Bruxelles: Peter Lang.

Tilly, C. (2001) 'Historical Analysis of Political Processes', in J. H. Turner (ed.) Handbook of Sociological Theory, pp. 567-88. New York: Kluwer Academic.

Tudor, H. (1972) The Political Myth. New York: Praeger.

Turner, V. W. (1974) The Ritual Process: Structure and Anti-Structure. Harmondsworth: Penguin.

Wallerstein, I. (1990) 'Culture as the Ideological Battleground of the Modern WorldSystem', in M. Featherstone (ed.) Global Culture. Nationalism, Globalization and Modernity, pp. 31-55. London: Sage.

Zerubavel, Y. (1995) Recovered Roots: Collective Memory and the Making of Israeli National Tradition. Chicago, IL: University of Chicago Press.

ELŻBIETA HAŁAS is Professor of Sociology at the University of Warsaw, Poland. Her research interests are in cultural sociology, symbolic interactionism, social symbolism and collective memory, interpretive social theory and history of sociology. Her recent books include: Interakcjonizm symboliczny. Społeczny kontekst znaczen [Symbolic Interactionism: The 
Social Context of Meanings] (Warsaw: Wydawnictwo Naukowe PWN, 2006); Symbole $w$ interakcji [Symbols in Interaction] (Warsaw: Oficyna Naukowa, 2001); and as editor: Symbols, Power and Politics (Frankfurt am Main: Peter Lang, 2002); Theodore Abel, The Columbia Circle of Scholars: Selections from the Journal 1930-1957 (Frankfurt am Main: Peter Lang, 2001). She is the editor of the Book Series 'Studies in Sociology: Symbols, Theory and Society' (Peter Lang). ADDRESS: Institute of Sociology, University of Warsaw, Karowa 18, 00-927 Warsaw, Poland.

[email: ehalas@poczta.neostrada.pl] 